Michał Dobrakowski ${ }^{1}$

\title{
THE EFFECT OF OCCUPATIONAL EXPOSURE TO LEAD ON THE NON-ENZYMATIC ANTIOXIDANT SYSTEM
}

\author{
WPŁYW PRZEWLEKŁEGO ZATRUCIA OŁOWIEM NA NIEENZYMATYCZNY UKŁAD ANTYOKSYDACYJNY
}

\author{
${ }^{1}$ Medical University of Silesia / Śląski Uniwersytet Medyczny w Katowicach, Zabrze, Poland \\ School of Medicine with the Division of Dentistry, Department of Biochemistry / Wydział Lekarski z Oddziałem Lekarsko-Dentystycznym, \\ Katedra Biochemii \\ ${ }^{2}$ Medical University of Silesia / Śląski Uniwersytet Medyczny w Katowicach, Zabrze, Poland \\ School of Medicine with the Division of Dentistry, Department of Chemistry / Wydział Lekarski z Oddziałem Lekarsko-Dentystycznym, \\ Katedra i Zakład Chemii
}

\begin{abstract}
Background: The role of non-enzymatic antioxidants, such as uric acid, albumin, bilirubin, and $\alpha$-tocopherol, in lead poisoning remains unclear. Therefore, the aim of the study was to explore the association between occupational exposure to lead and nonenzymatic antioxidant concentrations in serum and plasma. Material and Methods: The study population consisted of 278 healthy male employees of lead-zinc plants, with 129 workers classified as having low lead exposure (blood lead level - PbB $=20-39.9 \mu \mathrm{g} / \mathrm{dl}$ ) and 149 workers classified as having high lead exposure $(\mathrm{PbB}=40-59.8 \mu \mathrm{g} / \mathrm{dl})$. The control group was composed of 73 healthy male administrative workers. No one from this group had blood lead level or zinc protoporphyrin (ZPP) level greater than normal levels, being $10 \mu \mathrm{g} / \mathrm{dl}$ and $2.5 \mu \mathrm{g} / \mathrm{g}$ of hemoglobin, respectively. In addition to the levels of $\mathrm{PbB}$ and $\mathrm{ZPP}$, serum levels of uric acid (UA), albumin, thiol groups of albumin, and bilirubin were determined. The ferric reducing ability of plasma (FRAP) and the plasma level of $\alpha$-tocopherol were also evaluated. Results: Lead exposure indices were significantly elevated in the examined subgroups as compared with the controls. Serum uric acid levels were significantly elevated in both subgroups, particularly in the group with high exposure. Serum bilirubin concentration was significantly elevated in the group with high exposure compared with the control group, while in the group with low exposure, it showed only a non-significant trend towards an increase. In contrast, ferric-reducing ability of plasma was not significantly greater in the examined subgroups as compared with the control group. Nevertheless, levels of albumin, thiol groups of albumin, and a-tocopherol levels were significantly decreased in the exposed subgroups compared with the control group. Conclusions: Occupational exposure to lead interferes with the blood non-enzymatic antioxidant system. Med Pr 2014;65(4):443-451
\end{abstract}

Key words: lead poisoning, antioxidants, uric acid, bilirubin, albumin, $\alpha$-tocopherol

\section{STRESZCZENIE}

Wstęp: Wpływ zatrucia ołowiem na nieenzymatyczny układ antyoksydacyjny nadal jest słabo poznany. Celem badania było określenie wpływu zawodowego narażenia na pyły ołowiu na nieenzymatyczny układ antyoksydacyjny u eksponowanych pracowników. Materiał i metody: Grupę badaną stanowiło 278 zdrowych pracowników (płci męskiej) huty cynku i ołowiu. Wyodrębniono 2 podgrupy - o niskim (stężenie ołowiu we krwi: $\mathrm{PbB}=20-39,9 \mu \mathrm{g} / \mathrm{dl}$ ) i wysokim narażeniu $(\mathrm{PbB}=40-59,8 \mu \mathrm{g} / \mathrm{dl})$. Do pierwszej podgrupy zakwalifikowano 129 pracowników, natomiast do drugiej z nich - 149. Grupę porównawczą stanowiło 73 zdrowych pracowników administracji, u których stężenie ołowiu oraz cynkoprotoporfiryny we krwi nie przekraczało dopuszczalnych norm (odpowiednio $10 \mu \mathrm{g} / \mathrm{dl}$ i $2,5 \mu \mathrm{g} / \mathrm{g}$ hemoglobiny). Stopień narażenia na ołów określono na podstawie stężenia ołowiu i cynkoprotoporfiryny we krwi. Ponadto oznaczono stężenia kwasu moczowego, albumin, grup tiolowych albumin, bilirubiny i $\alpha$-tokoferolu. Określono także wartość tzw. zdolności redukującej osocza (ferric reducing ability of plasma - FRAP). Wyniki: Wartości biomarkerów narażenia na ołów były znamiennie wyższe w grupie badanej. Stężenie kwasu moczowego w surowicy było znamiennie wyższe w obu jej podgrupach z tendencją do wyższych wartości w podgrupie o większym narażeniu na ołów. W podgrupie tej stwierdzono także znamiennie wyższe stężenie bilirubiny w surowicy, podczas gdy w drugiej podgrupie wykazano tylko tendencję wzrostową tego parametru. Wartości FRAP nie różniły się zamiennie między grupami. Z kolei wartości pozostałych analizowanych parametrów (albuminy, grupy tiolowie albumin, $a$-tokoferol) były znamiennie niższe w badanych podgrupach względem grupy porównawczej. Wnioski: Zawodowe narażenie na pyły ołowiu modyfikuje funkcję nieenzymatycznego układu antyoksydacyjnego. Med. Pr. 2014;65(4):443-451

Słowa kluczowe: zatrucie ołowiem, antyoksydanty, kwas moczowy, bilirubina, albuminy, a-tokoferol 
Corresponding author / Autor do korespondencji: Michał Dobrakowski, Medical University of Silesia,

School of Medicine with Division of Dentistry, Department of Biochemistry, Jordana 19, 41-808 Zabrze, Poland,

e-mail: michal.dobrakowski@poczta.fm

Received: 2013, October 15, accepted: 2014, February 19

\section{INTRODUCTION}

Inorganic lead is one of the earliest identified occupational toxins (1). Sources of lead exposure include the manufacture of ammunition, batteries, sheet lead, some brass and bronze plumbing, ceramic glazes, caulking, radiation shields, circuit boards, military equipment, intravenous pumps, fetal monitors, and some surgical equipment (2).

Lead has a strong affinity for sulfhydryl (thiol) groups and therefore may inhibit the activity of numerous enzymes, including delta-aminolevulinic acid dehydratase (ALAD). The interference with ALAD inhibits heme biosynthesis and results in ALA accumulation (delta-aminolevulinic acid). Thus, blood ALA levels could be used as a biomarker of lead exposure. The activity of ferrochelatase, the enzyme that catalyzes iron insertion into protoporphyrin IX, is also impaired by lead. This impairment causes zinc-protoporphyrin formation, which could also be used as a biomarker of lead toxicity (3).

The physiological targets most affected by lead toxicity include the cardiovascular system, the hematopoietic system, renal and hepatic functions, the reproductive system (4), and the nervous system (5). The characteristic clinical manifestations of chronic exposure to lead include: abdominal pain, nausea, short-term memory loss, depression, loss of coordination, numbness and tingling in the extremities, constipation, inability to concentrate, and impotence (2).

Oxidative stress has been reported to be the primary contributory agent in the pathogenesis of plumbism. Lead can not only generate reactive oxygen species (ROS), but also be able to deplete antioxidant reserves (6). Furthermore, elevated levels of ALA, characteristic of plumbism, generate hydrogen peroxide and superoxide radicals. ALA also interacts with oxyhemoglobin. This interaction results in the generation of hydroxyl radicals, the most reactive free radicals (7). Lead-induced oxidative stress damages various cellular components, such as proteins, lipids, and DNA (4).

Lead interferes with both the enzymatic and nonenzymatic antioxidant defenses $(7,8)$.
The role of other non-enzymatic antioxidants, such as uric acid, albumin, bilirubin, and $\alpha$-tocopherol, in lead poisoning remains unclear. Their concentrations may be changed as a result of lead-induced dysfunctions of the kidneys, liver, or gastrointestinal tract. Alternatively, concentrations of these endogenous antioxidants may influence lead-induced oxidative stress. Recent reports concerning these interferences are inconsistent. Therefore, the present study was designed to explore the association between occupational lead exposure and non-enzymatic antioxidant concentrations in serum and plasma. This is the first study to simultaneously investigate many parameters associated with the function of the non-enzymatic antioxidant system in lead exposure.

\section{MATERIAL AND METHODS}

\section{Study subjects}

A total of 278 male employees of zinc and lead plants located in the southern region of Poland participated in the present study. The workers' mean age was $40.8 \pm 9.6$ years. The mean duration of employment was $16.4 \pm 10.2$ years. None of the subjects had a history of any chronic disease.

Blood concentrations of lead $(\mathrm{PbB})$ and zinc protoporphyrin (ZPP) and urine delta-aminolevulinic acid (ALA) levels were measured on average every 3 months for 2 years. Mean levels of lead, ZPP and ALA in the blood and urine were calculated $\left(\mathrm{PbB}_{\text {mean }}\right.$, $\left.\mathrm{ZPP}_{\text {mean }}, \mathrm{ALA}_{\text {mean }}\right)$ using the obtained values. The examined group was divided into 2 subgroups: low exposure to lead (LE) and high exposure to lead (HE). The division was arbitrarily based on the mean concentrations of blood lead level $\left(\mathrm{PbB}_{\text {mean }}\right)$. The 1st group included 129 workers with $\mathrm{PbB}_{\text {mean }}<40 \mu \mathrm{g} / \mathrm{dl}\left(\mathrm{PbB}_{\text {mean }}=\right.$ $20-39.9 \mu \mathrm{g} / \mathrm{dl})$, and the 2 nd group included 149 workers with $\mathrm{PbB}_{\text {mean }} \geq 40 \mu \mathrm{g} / \mathrm{dl}\left(\mathrm{PbB}_{\text {mean }}=40.0-59.8 \mu \mathrm{g} / \mathrm{dl}\right)$.

In the final set of blood samples, in addition to the levels of PbB and ZPP, serum levels of uric acid (UA), albumin, thiol groups of albumin, and total bilirubin were determined. The ferric reducing ability of plasma (FRAP) and the plasma level of $\alpha$-tocopherol were also evaluated. 
The control group was composed of 73 healthy male administrative workers with mean age 41.5 \pm 9.2 years. No one from this group had PbB or ZPP levels greater than normal levels, which were $10 \mu \mathrm{g} / \mathrm{dl}$ and $2.5 \mu \mathrm{g} / \mathrm{g} \mathrm{Hgb}$, respectively. All of the individuals from this group had no history of occupational exposure to lead. The experimental set-up has been approved by the Bioethics Committee of the Medical University of Silesia in Katowice, Poland (Decision No. NN-650136/I/06).

\section{Sampling and laboratory procedures}

Blood was drawn by venipuncture. A total of $15 \mathrm{ml}$ of blood from each was placed in a tube containing disodium ethylenediamine-tetraacetic acid (EDTA) solution as an anticoagulant to obtain plasma and erythrocytes, and $10 \mathrm{ml}$ of blood was collected into a plain tube in order to obtain serum.

Whole blood was used to analyze levels of lead and zinc protoporphyrin. $\mathrm{PbB}$ levels were analyzed using graphite furnace atomic absorption spectrophotometry on Unicam 929 and 939OZ Atomic Absorption Spectrometers with GF90 and GF90Z Graphite Furnaces. Data is presented as $\mu \mathrm{g} / \mathrm{dl}$. Concentration of zinc protoporphyrin in the blood was measured directly using the 206 Aviv Biomedical hematofluorometer, with an excitation wavelength of $415 \mathrm{~nm}$ and an emission wavelength of $596 \mathrm{~nm}$. The instrument measures the ratio of ZPP as a fluorescent substance to the absorption of light in the sample (hemoglobin), displayed as $\mu \mathrm{g}$ ZPP per gram of hemoglobin ( $\mu \mathrm{g} / \mathrm{g} \mathrm{Hb}$ ). Urine levels of delta-aminolevulinic acid were measured using the method of Grabecki et al. (9) and were expressed in $\mathrm{mg} / \mathrm{l}$.

After the centrifugation of the remaining whole blood, plasma was collected. Sedimented red blood cells were washed 3 times with $0.9 \% \mathrm{NaCl}$ and then lysed with bidistilled water. The concentration of hemoglobin in a $10 \%$ hemolysate was determined by the cyanmethemoglobin method with Drabkin's reagent.

Ferric-reducing ability of plasma (FRAP) was determined by the method of Benzie and Strain (10) using the EM 280 biochemical analyzer (Emapol, Poland) at a wavelength of $593 \mathrm{~nm}$. Data is shown in $\mu \mathrm{mol} / \mathrm{l}$. Concentrations of $\alpha$-tocopherol in plasma were measured by Shearer (11) using high-performance liquid chromatography with a Spherimage 80 ODS2 column and a UV/Vis detector (Knauer, Germany). Calculations were performed using EuroChrom 2000 software (Knauer, Germany). Results are shown in $\mu \mathrm{mol} / \mathrm{l}$.
Levels of uric acid (UA), albumin, protein and total bilirubin were measured by means of the A25 biochemical analyzer (BioSystems, Spain) according to the manufacturer's instructions. Results for UA and bilirubin are shown in $\mu \mathrm{mol} / \mathrm{l}$, and those for albumin and protein levels are expressed in $\mathrm{g} / \mathrm{l}$. Concentrations of thiol groups of albumin were measured according to the method of Koster et al. (12), results are shown in $\mu \mathrm{mol} / \mathrm{g}$ of protein.

\section{Statistical analysis}

Statistica 9.1 PL software was used to perform the statistical analysis. Statistical methods included the mean and standard deviation. Levene's test was used to verify the homogeneity of variances, and Shapiro-Wilk's test was used to verify normality. Statistical comparisons were performed using Student's t-test, a t-test with separate variance estimates, or a Mann-Whitney $U$ test. A Spearman non-parametric correlation was calculated. The value of $\mathrm{p}<0.05$ was considered to be significant.

\section{RESULTS}

The mean age, body mass index (BMI), and smoking habits were similar between the examined subgroups and the controls (Table 1).

The mean $\mathrm{PbB}, \mathrm{ZPP}$, and ALA were significantly elevated, by $426 \%, 171 \%$, and $56 \%$, respectively, in the LE group relative to the control group. These biomarkers were also elevated, by $623 \%, 317 \%$, and $86 \%$, respectively, in the $\mathrm{HE}$ group relative to the control group (Table 1).

The serum UA levels were significantly elevated, by $7 \%$ and $16 \%$ in the LE and HE groups, respectively, in comparison to the controls. Serum bilirubin concentration was significantly elevated by $15 \%$ in the HE group compared with the control group, while in the LE group, it only showed an insignificant tendency to increase. In contrast, FRAP values were not significantly greater in the LE and HE groups as compared with the control group. The levels of albumin, thiol groups of albumin, and a-tocopherol were significantly decreased, by $4 \%, 12 \%$, and $17 \%$, respectively, in the LE group and by $6 \%, 13 \%$, and $19 \%$, respectively, in the HE group compared with the control group (Table 1, Figure 1).

Spearman correlation showed that there were positive correlations between the markers of lead-exposure and UA levels. Moreover, the markers in question correlated negatively with the concentrations of albumin and the thiol groups of albumin (Table 2). 


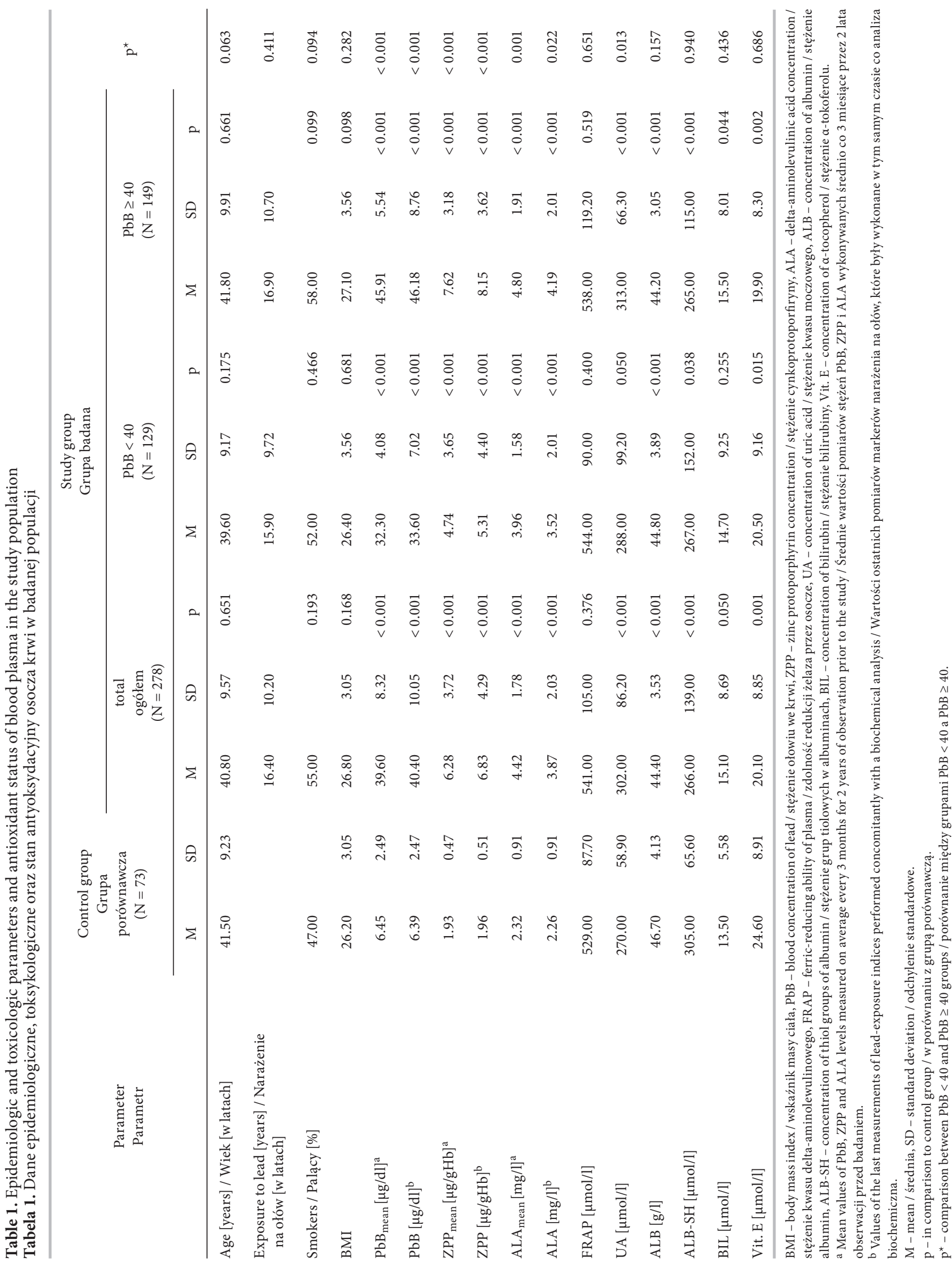




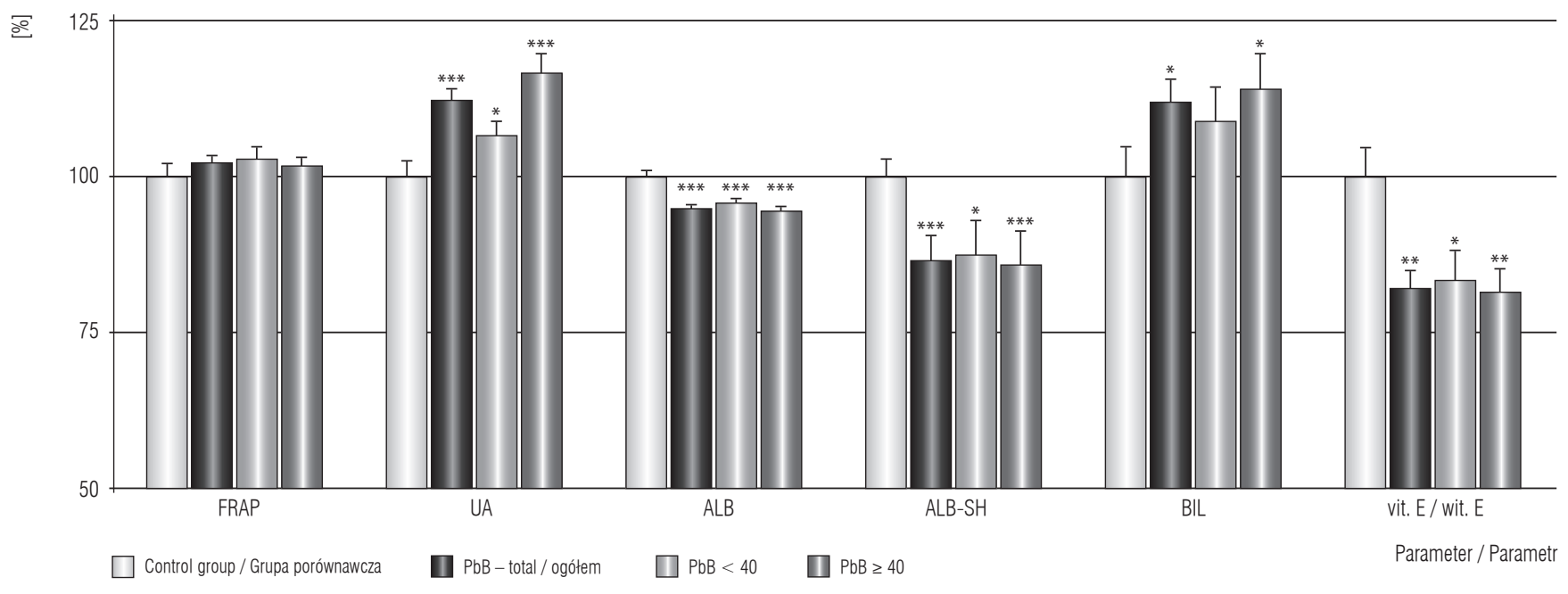

${ }^{*} \mathrm{p}<0.05 ;{ }^{* *} \mathrm{p}<0.01 ;{ }^{* * *} \mathrm{p}<0.001$ vs. control group / vs grupa porównawcza.

Abbreviations as in Table 1 / Skróty jak w tabeli 1 .

Fig. 1. Antioxidant status of blood plasma in lead exposed groups presented as a percentage of the values obtained from the control group Ryc. 1. Stan antyoksydacyjny osocza krwi badanej populacji przedstawiony jako procent wartości uzyskanych w grupie porównawczej

Table 2. Correlations among the study parameters (Spearman $\mathrm{R}$ values, $\mathrm{p}<0.05$ )

Tabela 2. Korelacje między badanymi parametrami (współczynnik R Spearmana, p < 0,05)

\begin{tabular}{|c|c|c|c|c|c|c|}
\hline $\begin{array}{l}\text { Parameter } \\
\text { Parametr }\end{array}$ & FRAP & UA & ALB & ALB-SH & BIL & Vit. E \\
\hline Age [years] / Wiek [w latach] & ns. & ns. & -0.17 & -0.23 & ns. & ns. \\
\hline $\begin{array}{l}\text { Exposure to lead [years] / Narażenie } \\
\text { na ołów [w latach] }\end{array}$ & ns. & ns. & ns. & ns. & ns. & ns. \\
\hline BMI & 0.13 & 0.21 & ns. & ns. & ns. & ns. \\
\hline $\mathrm{PbB}$ & ns. & 0.23 & -0.29 & -0.28 & ns. & ns. \\
\hline $\mathrm{ZPP}_{\text {mean }}$ & ns. & 0.20 & -0.25 & -0.27 & ns. & ns. \\
\hline $\mathrm{ZPP}$ & ns. & 0.18 & -0.25 & -0.24 & ns. & ns. \\
\hline $\mathrm{ALA}_{\text {mean }}$ & ns. & 0.20 & -0.24 & -0.34 & ns. & ns. \\
\hline
\end{tabular}

ns. - not statistically significant / nieistotne statystycznie.

Other abbreviations as in Table 1 / Inne skróty jak w tabeli 1.

\section{DISCUSSION}

Associations between lead-exposure and levels of nonenzymatic antioxidants have been studied by many researchers, however, results are inconsistent and should be verified. In the present study, many parameters associated with the function of the non-enzymatic antioxidant system have been investigated, bringing some new information, especially about the dose-effect dependence between blood lead level and antioxidant concentration.
Uric acid (UA) is the end product of purine metabolism and acts as a scavenger of peroxynitrate. As a natural antioxidant, UA accounts for up to $60 \%$ of blood antioxidative capacity (13). UA levels in the lead-exposed subgroups were significantly elevated in a dose-dependent manner. Specifically, the increase was significantly higher in the HE group compared with the LE group.

Other human studies partially support the results of the present study. A significant increase in the UA levels in lead-exposed workers $(\mathrm{PbB}=29.1 \mu \mathrm{g} / \mathrm{dl})$ was reported in a study by Khan et al. (14) as well. Bener et al. (15) 
also found significantly increased UA levels in workers exposed to high doses of lead ( $\mathrm{PbB}=80.9 \mu \mathrm{g} / \mathrm{dl}$ ). Consistently, a positive correlation between blood lead levels and UA concentrations was found in several studies (16-18). Furthermore, the comparison of 2 groups of workers with $\mathrm{PbB} \leq 60 \mu \mathrm{g} / \mathrm{dl}$ and $\mathrm{PbB}>60 \mu \mathrm{g} / \mathrm{dl}$ showed a significant difference in the UA concentrations. The authors postulated that subjects with blood lead levels greater than $60 \mu \mathrm{g} / \mathrm{dl}$ had increased chances of developing adverse renal effects. However, Omae et al. (19) indicated that blood lead levels below $70 \mu \mathrm{g} / \mathrm{dl}$ may not be associated with adverse effects on renal function. In contrast, a study comparing aboriginals and non-aboriginals in Taiwan indicated a higher risk for renal dysfunction in people with blood lead levels exceeding $7.5 \mu \mathrm{g} / \mathrm{dl}(20)$.

However, unchanged UA concentrations in lead smelter workers $(\mathrm{PbB}=46.6 \mu \mathrm{g} / \mathrm{dl})$ were reported by Roels et al. (21). Similarly, Konishi et al. (22) found no association between UA and blood lead levels in leadexposed workers $(\mathrm{PbB}=3.9-107.7 \mu \mathrm{g} / \mathrm{dl})$. These results are consistent with those of Weaver et al. (23) who also observed no association between blood lead levels and uric acid, after adjusting for age, sex, body mass index, and alcohol use. However, this study did indicate that older workers are more susceptible to the development of hyperuricemia due to lead exposure.

Despite some discrepancies among the studies described above, a dose-effect relationship between blood lead and UA levels may exist. Several mechanisms may cause increases in UA levels. High concentrations and long residence time of lead in the renal tubular epithelial cells make kidneys susceptible to lead-induced oxidative stress and inflammation (14). Therefore, hyperuricemia may be due to increased tubular reabsorption or decreased tubular secretion of UA $(17,23)$. In addition, because lead nephropathy is associated with interstitial fibrosis and glomerular sclerosis (18), decreased glomerular filtration may result in elevated UA levels. Finally, the increase in UA concentrations may be a result of lead-induced alterations in purine metabolism. However, it should be noted that UA is known to be a nephrotoxicant (20), and the renal pathologies that occur in plumbism could, to some extent, be secondary to hyperuricemia. Contradictory results of studies regarding the association between lead toxicity and UA level may be caused by differences in the specific materials and methods of a particular study. Such variables would determine unique combinations of the several plausible mechanisms to be triggered by lead.
The antioxidant properties of albumin are attributed to the cysteine thiol groups that determine plasma redox status. Thiol groups act as ROS scavengers and take part in thiol exchange reactions. In addition, albumin sequesters prooxidant molecules and redoxactive metals. Moreover, albumin has been proposed to have a thioredoxin-dependent lipid hydroperoxide reductase activity in vitro $(13,24)$.

Concentrations of both albumin and albumin thiols were significantly decreased in the present study. Our results are supported by a study of Mikhail et al. (25), who observed decreases in serum albumin and total protein levels, as well as a reversed albumin/globulin ratio in lead tank welders $(\mathrm{PbB}=42.19 \mu \mathrm{g} / \mathrm{dl})$. This study indicated the initial stages of fatty infiltration of the workers' livers. Khan et al. (14) also found decreased serum albumin and total protein levels in workers. However, Al-Neamy et al. (26) reported unchanged albumin and total protein levels in industrial workers exposed to lead $(\mathrm{PbB}=77.5 \mu \mathrm{g} / \mathrm{dl})$.

Reduction in albumin and protein levels may be caused by lead-induced inhibition of protein biosynthesis $(27,28)$. This hypothesis was supported by Koo et al. (29), who observed a decrease in albumin mRNA in rat liver after the administration of lead nitrate. In a study by Shalan et al. (30), lead reduced the total RNA content in rat livers, indicating a lower rate of protein biosynthesis. One possible mechanism for this effect is that protein biosynthesis could be downregulated by lead-induced alterations in excretion of hormones, such as triiodothyronine (27).

The decrease in albumin thiol groups in the present study was greater than the decrease in albumin. This result could have been due to the binding of lead to thiol groups and the elevated utilization of thiol groups under oxidative stress conditions. Diminished thiol contents in experimental lead exposure were reported in rats $(31,32)$ and calves $(33)$. Simultaneously, elevated parameters of lipid peroxidation were shown.

Bilirubin is an end product in heme metabolism. Heme is degraded by heme oxygenase $(\mathrm{HO})$ to biliverdin, which is in turn converted to bilirubin by biliverdin reductase. Bilirubin is known to have toxic effects at high concentrations. However, under physiological conditions, bilirubin possesses strong antioxidant potential against peroxyl radicals. Bilirubin can act synergically with $\alpha$-tocopherol to protect lipids from $\operatorname{ROS}(34,35)$. Noriega et al. (36) showed that bilirubin decreases ALA toxicity in rats. Decreased lipid peroxidation, increased glutathione (GSH) concentrations, and elevated 
activities of antioxidant enzymes were observed in this study as a result of bilirubin administration.

Serum bilirubin level was elevated in the present study. Consistent results were presented in several studies. Ibrahim et al. (27) reported elevated plasma bilirubin levels in rats that were treated with lead acetate. Similarly, when examining rats exposed to lead through intraperitoneal injections, Abdel-Moneim et al. (37) observed elevated serum bilirubin concentrations. Berrahal et al. (34) observed significantly increased plasma bilirubin levels in rats that had been injected with $15 \mathrm{mg} / \mathrm{kg}$ of lead acetate. However, lead acetate in a dose of $5 \mathrm{mg} / \mathrm{kg}$ was not sufficient to induce bilirubin level elevation. Nevertheless, in studies of Mikhail et al. (25) and Al-Neamy et al. (26) bilirubin levels showed only an insignificant tendency to increase in workers exposed to lead, whereas Khan et al. (14) reported that bilirubin concentration was not significantly decreased.

An inducible isoform of heme oxygenase is HO-1. Specific induction of HO-1 determines the adaptive response of cells to oxidative stress, especially in myocardium or nervous tissues, in which antioxidant defense is less robust (34). Lead exposure has been confirmed to induce HO-1 activity $(38,39)$. This induction is a possible explanation for elevated bilirubin levels in lead poisoning. Due to the fact that the elevation of bilirubin level was significantly higher in the HE group compared with the control group and not significantly higher in the LE group compared with the control group, it is reasonable to expect that lead induces HO-1 in a dose-dependent manner.

'Vitamin E' is a term that is used to describe at least 8 naturally occurring compounds. Alpha-tocopherol possesses the highest biological activity. Alphatocopherol interacts directly with ROS and protects biological membranes and lipoproteins from oxidative stress by limiting the propagation of lipid peroxidation. Furthermore, $\alpha$-tocopherol regulates the function of the antioxidant defense system by modulating signal transduction pathways $(4,40)$.

Results of the recent studies indicate that vitamin $\mathrm{E}$ could be useful in protecting membrane lipids from lead-induced oxidative stress. It was reported that supplementation with the vitamin may increase glutathione production and lower lipid peroxide concentrations (41). This supplementation may also prevent the lead-induced inhibition of superoxide dismutase (SOD) and catalase (42). Furthermore, $\alpha$-tocopherol weakly increases ALAD levels in rabbits with chronic plumbism (43).
Serum concentrations of $a$-tocopherol were significantly decreased in the present study. Decreased a-tocopherol concentrations were also reported in a study by Ergurhan-Ilhan et al. (42) who examined apprentices exposed to low doses of lead $(\mathrm{PbB}=7.9 \pm 5.2 \mu \mathrm{g} / \mathrm{dl})$. Moreover, Caylak et al. (44) showed decreased level of vitamin $\mathrm{E}$ in rats that were orally exposed to lead acetate.

The FRAP value reflects the antioxidant and reducing potentials of biological fluids (10). Although lead induces oxidative stress, FRAP levels were unchanged in the examined subgroups. Therefore, elevated UA and bilirubin concentrations may compensate for the decreases in albumin, albumin thiols, and a-tocopherol levels, or other compensatory mechanisms may occur.

\section{CONCLUSIONS}

Occupational lead exposure interferes with the nonenzymatic antioxidant system in blood without change in the reducing capacity of plasma.

\section{REFERENCES}

1. Gidlow DA. Lead toxicity. Occup Med (Lond). 2004; 54(2):76-81, http://dx.doi.org/10.1093/occmed/kqh019.

2. Patrick L. Lead toxicity, a review of the literature. Part 1 : Exposure, evaluation, and treatment. Altern Med Rev. 2006;11(1):2-22.

3. Sakai T. Biomarkers of lead exposure. Ind Health. 2000;38(2):127-42, http://dx.doi.org/10.2486/ indhealth.38.127.

4. Hsu PC, Guo YL. Antioxidant nutrients and lead toxicity. Toxicology. 2002;180(1):33-44, http://dx.doi.org/10. 1016/S0300-483X(02)00380-3.

5. Jakubowski M. Low-level environmental lead exposure and intellectual impairment in children: The current concepts of risk assessment. Int J Occup Med Environ Health. 2011;24(1):1-7, http://dx.doi.org/10.2478/s13382011-0009-z.

6. Kasperczyk A, Prokopowicz A, Dobrakowski M, Pawlas N, Kasperczyk S. The effect of occupational lead exposure on blood levels of zinc, iron, copper, selenium and related proteins. Biol Trace Elem Res. 2012;150(1-3): 49-55, http://dx.doi.org/10.1007/s12011-012-9490-x.

7. Patrick L. Lead toxicity. Part II: The role of free radical damage and the use of antioxidants in the pathology and treatment of lead toxicity. Altern Med Rev. 2006;11(2):114-27. 
8. Gurer H, Ercal N. Can antioxidants be beneficial in the treatment of lead poisoning? Free Radic Biol Med. 2000;29(10):927-45, http://dx.doi.org/10.1016/S08915849(00)00413-5.

9. Grabecki J, Haduch T, Urbanowicz H. [Simple determination methods of delta-aminolevulinic acid in urine]. Int Arch Arbeitsmed. 1967;23(3):226-40. German.

10. Benzie IFF, Strain JJ. The ferric reducing ability of plasma (FRAP) as a measure of "antioxidant power": The FRAP assay. Anal Biochem. 1996;239(1):70-6.

11. Shearer MJ. Vitamins. In: Lim CK, editor. HPLC of small molecules. A practical approach. Oxford: IRL Press; 1986. p. 157-219.

12. Koster JF, Biemond P, Swaak AJ. Intracellular and extracellular sulphydryl levels in rheumatoid arthritis. Ann Rheum Dis. 1986;45(1):44-6, http:/dx.doi.org/10.1136/ ard.45.1.44.

13. Peng F, Yang Y, Liu J, Jiang Y, Zhu C, Deng X, et al. Low antioxidant status of serum uric acid, bilirubin and albumin in patients with neuromyelitis optica. Eur J Neurol. 2012;19(2):277-83, http://dx.doi.org/10.1111/j.14681331.2011.03488.x.

14. Khan DA, Qayyum S, Saleem S, Khan FA. Lead-induced oxidative stress adversely affects health of the occupational workers. Toxicol Ind Health. 2008;24(9):611-8, http://dx.doi.org/10.1177/0748233708098127.

15. Bener A, Obineche E, Gillett M, Pasha MAH, Bishawi B. Association between blood levels of lead, blood pressure and risk of diabetes and heart disease in workers. Int Arch Occup Environ Health. 2001;74(5):375-8, http://dx.doi.org/10.1007/s004200100231.

16. Hernández-Serrato MI, Fortoul TI, Rojas-Martínez R, Mendoza-Alvarado LR, Canales-Treviño L, Bochichio-Riccardelli $\mathrm{T}$, et al. Lead blood concentrations and renal function evaluation: Study in an exposed Mexican population. Environ Res. 2006;100(2):227-31, http://dx.doi.org/10.1016/j.envres.2005.03.004.

17. Ehrlich R, Robins T, Jordaan E, Miller S, Mbuli S, Selby P, et al. Lead absorption and renal dysfunction in a South African battery factory. Occup Environ Med. 1998;55(7): 453-60, http://dx.doi.org/10.1136/oem.55.7.453.

18. Wang VS, Lee MT, Chiou JY, Guu CF, Wu CC, Wu TN, et al. Relationship between blood lead levels and renal function in lead battery workers. Int Arch Occup Environ Health. 2002;75(8):569-75, http://dx.doi.org/10.1007/ s00420-002-0362-0.

19. Omae K, Sakurai H, Higashi T, Muto T, Ichikawa M, Sasaki N. No adverse effects of lead on renal function in lead-exposed workers. Ind Health. 1990;28(2):77-83, http://dx.doi.org/10.2486/indhealth.28.77.
20. Lai LH, Chou SY, Wu FY, Chen JJH, Kuo HW. Renal dysfunction and hyperuricemia with low blood lead levels and ethnicity in community-based study. Sci Total Environ. 2008;401(1-3):39-43, http://dx.doi.org/10. 1016/j.scitotenv.2008.04.004.

21. Roels H, Lauwerys R, Konings J, Buchet JP, Bernard A, Green $S$, et al. Renal function and hyperfiltration capacity in lead smelter workers with high bone lead. Occup Environ Med. 1994;51(8):505-12, http://dx.doi.org/ 10.1136/oem.51.8.505.

22. Konishi Y, Endo G, Kiyota A, Horiguchi S. Fractional clearances of low molecular weight proteins in lead workers. Ind Health. 1994;32(3):119-28, http://dx.doi. org/10.2486/indhealth.32.119.

23. Weaver VM, Jaar BG, Schwartz BS, Todd AC, Ahn KD, Lee SS, et al. Associations among lead dose biomarkers, uric acid, and renal function in Korean lead workers. Environ Health Perspect. 2005;113(1):36-42, http://dx.doi.org/10.1289/ehp.7317.

24. Turell L, Carballal S, Botti H, Radi R, Alvarez B. Oxidation of the albumin thiol to sulfenic acid and its implications in the intravascular compartment. Braz J Med Biol Res. 2009;42:305-11, http://dx.doi.org/10.1590/ S0100-879X2009000400001.

25. Mikhail TH, El-Sawaf HA, Ibrahim KM, Awadallah R, El-Dessoukey EA. Evaluation of the effect of lead exposure on the liver in Egyptian lead tank welders. Z Ernahrungswiss. 1980;19(1):50-6, http://dx.doi.org/ 10.1007/BF02021073.

26. Al-Neamy FRM, Almehdi AM, Alwash R, Pasha MAH, Ibrahim A, Bener A. Occupational lead exposure and amino acid profiles and liver function tests in industrial workers. Int J Environ Health Res. 2001;11(2):181-8, http://dx.doi.org/10.1080/09603120020047564.

27. Ibrahim NM, Eweis EA, El-Beltagi HS, Abdel-Mobdy YE. Effect of lead acetate toxicity on experimental male albino rat. Asian Pac J Trop Biomed. 2012;2(1): 41-6, http://dx.doi.org/10.1016/S2221-1691(11)60187-1.

28. Bandhu HK, Dani V, Garg ML, Dhawan DK. Hepatoprotective role of zinc in lead-treated, protein-deficient rats. Drug Chem Toxicol. 2006;29:11-24, http://dx.doi. org/10.1080/01480540500408507.

29. Koo P, Nagai MK, Farber E. Multiple sites of control of glutathione S-transferase P1-1 in rat liver. J Biol Chem. 1994;269:14601-6.

30. Shalan MG, Mostafa MS, Hassouna MM, El-Nabi SEH, El-Refaie A. Amelioration of lead toxicity on rat liver with vitamin $\mathrm{C}$ and silymarin supplements. Toxicology. 2005;206(1):1-15, http://dx.doi.org/10.1016/j.tox. 2004.07.006. 
31. El-Missiry MA. Prophylactic effect of melatonin on lead-induced inhibition of heme biosynthesis and deterioration of antioxidant systems in male rats. J Biochem Mol Toxicol. 2000;14(1):57-62, http://dx.doi.org/10.1002/ (SICI)1099-0461(2000)14:1<57::AID-JBT8>3.0.CO;2-B.

32. Tandon SK, Prasad S, Singh S, Shukla M, Chatterjee M. Influence of age on lead-induced oxidative stress in rat. Biol Trace Elem Res. 2002;88(1):59-69, http://dx.doi.org/ 10.1385/BTER:88:1:59.

33. Patra RC, Swarup D. Effect of lead on erythrocytic antioxidant defense, lipid peroxide level and thiol groups in calves. Res Vet Sci. 2000;68(1):71-4, http://dx.doi.org/ 10.1053/rvsc.1999.0340.

34. Berrahal AA, Nehdi A, Hajjaji N, Gharbi N, El-Fazâa S. Antioxidant enzymes activities and bilirubin level in adult rat treated with lead. C R Biol. 2007;330(8):581-8, http://dx.doi.org/10.1016/j.crvi.2007.05.007.

35. Fuhua P, Xuhui D, Zhiyang Z, Ying J, Yu Y, Feng T, et al. Antioxidant status of bilirubin and uric acid in patients with myasthenia gravis. Neuroimmunomodulation. 2012;19(1):43-9, http://dx.doi.org/10.1159/000327727.

36. Noriega GO, Tomaro ML, del Batlle AMC. Bilirubin is highly effective in preventing in vivo $\delta$-aminolevulinic acid-induced oxidative cell damage. Biochim Biophys Acta. 2003;1638(2):173-8, http://dx.doi.org/10.1016/ S0925-4439(03)00081-4.

37. Abdel-Moneim AE, Dkhil MA, Al-Quraishy S. The redox status in rats treated with flaxseed oil and lead-induced hepatotoxicity. Biol Trace Elem Res. 2011;143(1):457-67, http://dx.doi.org/10.1007/s12011-010-8882-z.

38. Korashy HM, El-Kadi AOS. Transcriptional and posttranslational mechanisms modulating the expression of the cytochrome P450 1A1 gene by lead in HepG2 cells: A role of heme oxygenase. Toxicology. 2012;291(1-3): 113-21, http://dx.doi.org/10.1016/j.tox.2011.11.006.

39. Vargas H, Castillo C, Posadas F, Escalante B. Acute lead exposure induces renal haeme oxygenase- 1 and decreases urinary $\mathrm{Na}$ excretion. Hum Exp Toxicol. 2003;22(5): 237-44, http://dx.doi.org/10.1191/0960327103ht360oa.

40. Patra RC, Swarup D, Dwivedi SK. Antioxidant effects of a tocopherol, ascorbic acid and L-methionine on lead induced oxidative stress to the liver, kidney and brain in rats. Toxicology. 2001;162(2):81-8, http://dx.doi.org/ 10.1016/S0300-483X(01)00345-6.

41. Rendón-Ramirez A, Cerbón-Solórzano J, MaldonadoVega M, Quintanar-Escorza MA, Calderón-Salinas JV. Vitamin-E reduces the oxidative damage on $\delta$-aminolevulinic dehydratase induced by lead intoxication in rat erythrocytes. Toxicol Vitro. 2007;21(6):1121-6, http://dx.doi.org/10.1016/j.tiv.2007.04.019.

42. Ergurhan-Ilhan I, Cadir B, Koyuncu-Arslan M, Arslan C, Gultepe FM, Ozkan G. Level of oxidative stress and damage in erythrocytes in apprentices indirectly exposed to lead. Pediatr Int. 2008;50(1):45-50, http://dx.doi.org/ 10.1111/j.1442-200X.2007.02442.x.

43. Bartlett RS, Rousseau Jr JE, Frier HI, Hall Jr RC. Effect of vitamin $\mathrm{E}$ on $\delta$-aminolevulinic acid dehydratase activity in weanling rabbits with chronic plumbism. J Nutr. 1974;104:1637-45.

44. Caylak E, Aytekin M, Halifeoglu I. Antioxidant effects of methionine, a-lipoic acid, N-acetylcysteine and homocysteine on lead-induced oxidative stress to erythrocytes in rats. Exp Toxicol Pathol. 2008;60(4-5):289-94, http://dx.doi.org/10.1016/j.etp.2007.11.004.

The use of the article „The effect of occupational exposure to lead on the non-enzymatic antioxidant system” is permitted under license conditions of Creative Commons Attribution-NonCommercial 3.0 (also known as CC-BY-NC), available at http://creativecommons.org/licenses/by-nc/3.0/pl/ or another language version of this license or any later version of this license published by Creative Commons / Zezwala się na korzystanie z artykułu „Wpływ przewlekłego zatrucia ołowiem na nieenzymatyczny układ antyoksydacyjny” na warunkach licencji Creative Commons Uznanie autorstwa Użycie niekomercyjne 3.0 (znanej również jako CC-BY-NC), dostępnej pod adresem http://creativecommons.org/licenses/by-nc/3.0/pl/ lub innej wersji językowej tej licencji, lub którejkolwiek późniejszej wersji tej licencji, opublikowanej przez organizację Creative Commons. 